\title{
Substrates containing agricultural residues provide better development of papaya seedlings
}

\section{Substratos contendo resíduos agrícolas proporcionam melhor desenvolvimento de mudas de mamoeiro}

\section{Ana Claudia $\operatorname{COSTA}^{1}$; Gessica Ferreira MARTINS ${ }^{2}$}

1 Autor para correspondência; Doutora em Agronomia; Universidade do Estado de Mato Grosso; Faculdade de Ciências Agrárias, Biológicas e Sociais Aplicadas; Av. Prof. Dr. Renato Figueiro Varella s/no - Cx Postal 08, CEP 78.690-000, Nova Xavantina - MT; anaclaudiacosta87@hotmail.com

${ }^{2}$ Engenheira Agrônoma; Universidade do Estado de Mato Grosso; gessicamartins12@outlook.com

Recebido em: 03-01-2018; Aceito em: 17-04-2018

\begin{abstract}
The use of organic residues in the formulation of substrates for the production of papaya seedlings may favor the physical, chemical, and biological properties of the soil, resulting in better quality seedlings. The objective of this work was to evaluate the effect of substrates formulated in ratios (residue:soil) with organic residues for the production of papaya (Carica papaya L.) seedlings. The experimental design was a randomized complete block design, in a 5 (residues) $\times 2$ (ratios) factorial scheme with an additional treatment (control), with three replications and the plots constituted by 10 plants. The treatments were: T1 - soybean residue + soil (1:2); T2 - soybean residue + soil (1:4); T3 - sugarcane residue + soil (1:2); T4 - sugarcane residue + soil (1:4); T5 - cotton residue + soil (1:2); T6 - cotton residue + soil (1:4); T7 - cattle manure + soil (1:2); T8 - cattle manure + soil (1:4); T9 - chicken manure + soil (1:2); T10 - chicken manure + soil (1:4); T11 (control) - soil (1: 1). The following variables were evaluated: plant height, stem diameter, number of leaves, fresh and dry mass of shoots and roots. The substrates containing cattle manure, sugarcane residue, and cotton residue, in the ratio 1:2 (residue:soil) (v/v), provided greater growth of the papaya seedlings. Alternatively, chicken manure may be employed, provided it is used in the ratio 1:4 (residue:soil).
\end{abstract}

Additional keywords: animal residue; Carica papaya L.; organic fertilization; vegetal residue.

\begin{abstract}
Resumo
A utilização de resíduos orgânicos na formulação de substratos para a produção de mudas de mamoeiro pode favorecer as propriedades físicas, químicas e biológicas do solo, resultando em mudas de melhor qualidade. O objetivo deste trabalho foi avaliar o efeito de substratos formulados com resíduos orgânicos em proporções (resíduo:solo) para a produção de mudas de mamoeiro (Carica papaya L.). O delineamento experimental utilizado foi o em blocos casualizados, em esquema fatorial 5 (resíduos) x 2 (proporções), com um tratamento adicional (testemunha), com três repetições, e as parcelas constituídas por 10 plantas. Os tratamentos foram: T1- resíduo de soja + solo (1:2); T2- resíduo de soja + solo (1:4); T3- resíduo de cana-de-açúcar + solo (1:2); T4- resíduo de cana-de-açúcar + solo (1:4); T5- resíduo de algodão + solo (1:2); T6- resíduo de algodão + solo (1:4); T7- esterco bovino + solo (1:2); T8- esterco bovino + solo (1:4); T9- esterco de galinha + solo (1:2); T10- esterco de galinha + solo (1:4); T11 (testemunha) - solo (1:1). Foram avaliadas as variáveis: altura, diâmetro do caule, número de folhas, massas fresca e seca da parte aérea e do sistema radicular. Os substratos contendo esterco bovino, resíduos de cana-de-açúcar e algodão, na proporção 1:2 (resíduo:solo) (v/v), proporcionaram maior crescimento das mudas de mamoeiro. Alternativamente, o esterco de galinha pode ser empregado desde que utilizado na proporção 1:4 (resíduo:solo).
\end{abstract}

Palavras-chave adicionais: adubação orgânica; Carica papaya L.; resíduo animal; resíduo vegetal.

\section{Introduction}

Papaya (Carica papaya L.) is a tropical fruit belonging to the family Caricaceae, which found ideal conditions to develop and produce properly in Brazil, although it is native to Central America, specifically the region near the Gulf of Mexico (Araújo et al., 2013). Despite being a very perishable fruit in post-harvest, papaya is an excellent source of calcium, vitamin $A$ and $C$, and is therefore widely used in diets (Anjos et al., 2015).

For the successful implantation of an orchard, it is necessary to use seedlings with phytosanitary quality and good nutritional status, since the seedling is considered the basis of production and one of the factors that most interferes with the growth and useful life of the orchard. The propagation of papaya is preferably carried out by means of seeds, which is considered a fast, economical, and practical method (Melo et al., 2015). 
In the production of high quality seedlings, it is important to use substrates that have adequate physical and chemical properties, and that provide the necessary nutrients for the development of the plant. The substrates must have absence of pathogens, low density, balanced chemical composition, and good cohesion between particles (Morais et al., 2017). The high cost of commercial substrates has led to the use of materials available on the property, such as soil, sand, and organic compounds, mainly among small farmers producing their own papaya seedlings (Bonatti et al., 2017). For the production of papaya seedlings, the main mixtures recommended for formulating the substrates are: $30 \%$ soil, $35 \%$ Plantmax $\AA$, and $35 \%$ goat manure (Araújo et al., 2010), or vegetal soil, sand, and cattle manure, in the ratio 1:1:2 (Lima et al., 2011).

The use of organic residues in the formulation of substrates for the production of papaya seedlings may favor the physical, chemical, and biological properties of the soil, resulting in high quality seedlings (Oliveira et al., 1994). It was verified that the soil cation exchange capacity (CEC) increases with the presence of organic residues, and some components resulting from the decomposition can act as stimulants for root growth (Malavolta et al., 2002). Furthermore, organic residues, especially those from the processing of products, can cause problems to the environment when disposed improperly (Silva et al., 2017).

Agricultural residues cause concern due to accommodation restrictions and risks of environmental contamination (Torres \& Tarifa, 2012). Thus, the increasing environmental pressure has led companies to seek alternatives to reuse waste from agricultural and industrial processes (Silva et al., 2014). The use of residues generated in a given region is also a way of minimizing the environmental impacts caused by their incorrect disposal in the environment (Krause et al., 2017).

The organic residue may be of animal or vegetable origin, resulting in organic matter after decomposition (Finatto et al., 2013). Cattle manure is one of the most commonly used organic fertilizers, both for seedling production and for use in already established orchards, due to its low cost and easy availability. The chemical composition of this type of manure is altered according to the animal species and the diet to which it is submitted (Malavolta et al., 2002). Poultry manures, in turn, are excellent sources of nitrogen and, depending on the diet of birds, the $\mathrm{N}$ content may vary significantly (Penteado, 2003). Finally, residues of vegetable origin are being increasingly used for their efficiency in providing nutrients, especially if incorporated into the soil; from 30 to $80 \%$ of the vegetable mass is left as organic remains, and this percentage varies according to the species (Korndörfer, 2015).

One of the important factors that must be considered in the formulation of a substrate is the proportion of each component used, since each material has its own characteristics, leading to increased or reduced quality as a function of different ratios. Therefore, it is necessary to analyze the formulation for an ideal nutrient availability (Almeida et al., 2012), adequate $\mathrm{pH}$ (Kusdra et al., 2008), good texture and structure (Silva et al., 2012).

Despite the great demand for research on waste reuse alternatives, few studies have been carried out in Brazil on this subject, mainly with residues from cotton, sugarcane, soybean, and livestock production activities. Thus, the use of substrates containing plant or animal residues may be a viable alternative to reuse such materials (Caldeira et al., 2008).

The objective of this work was to evaluate the effect of substrates formulated with organic residues in different ratios (residue:soil) in the production of papaya (Carica papaya L.) seedlings.

\section{Materials and methods}

The experiment was carried out from June to August 2016 in the nursery of the Mato Grosso State University (UNEMAT), located in the Campus of Nova Xavantina-MT, in the vicinity of the municipal reserve Mário Viana Park, popularly known as "Parque do Bacaba" (14\%41'25" S; 52 $20^{\prime} 55^{\prime \prime} \mathrm{W}$ ), located at an average altitude of $306 \mathrm{~m}$, in the northwest region of the state of Mato Grosso. According to the KöppenGeiger classification (1928), the climate of this region can be classified as Aw, that is, it has two clearly defined seasons, with dry season from April to September, and rainy season from October to March.

For the production of papaya seedlings, three seeds of the Formosa group of the Isla ${ }^{\circledR}$ brand were sown in each black polyethylene bag with capacity for $1.8 \mathrm{dm}^{3}(15 \times 25 \mathrm{~cm})$ of substrate. Different ratios of plant and animal residues in mixture with soil were used as substrates, these being determined according to the volume $(\mathrm{v} / \mathrm{v})$. The seedlings were placed on plastic benches at a height of $1.2 \mathrm{~m}$ from the ground, in a Polysack $\AA$ Sombrite shade screening with $50 \%$ luminosity.

The experimental design consisted of a randomized block design, in a 5 (residues) $\times 2$ (ratios) factorial scheme with an additional treatment (control) containing soil as substrate, totaling eleven treatments, with three replications and the plots constituted by 10 plants. The treatments were: T1 - soybean residue + soil (1:2); T2 - soybean residue + soil (1:4); T3 - sugarcane residue + soil (1:2); T4 - sugarcane residue + soil (1:4); T5 - cotton residue + soil (1:2); T6 - cotton residue + soil (1:4); T7 - cattle manure + soil (1:2); T8 - cattle manure + soil (1:4); T9 - chicken manure + + soil (1:2); T10 - chicken manure + soil (1:4); T11 - soil (1:1).

The residues were obtained from farms located in the vicinity of Nova Xavantina, with the plant residues being purchased by these farms from agricultural cooperatives in the region. The soybean residue was obtained from the extraction of soybean (Glycine max) oil, constituting the bran; the cotton (Gossypium sp.) residue, known as pie, came from the extraction of almond oil; and the sugarcane 
(Saccharum sp.) residue was the by-product resulting from sugarcane crushing, constituting the bagasse. All animal and vegetable residues were exposed to direct sunlight for 60 days before being used in the formula- tion of the substrates, without grinding. The physical and chemical analysis of the soil used as substrate is presented in Table 1, and the chemical analyses of the residues used are presented in Table 2.

Table 1- Chemical and physical soil analysis used as substrate for the production of papaya seedlings in the municipality of Nova Xavantina-MT.

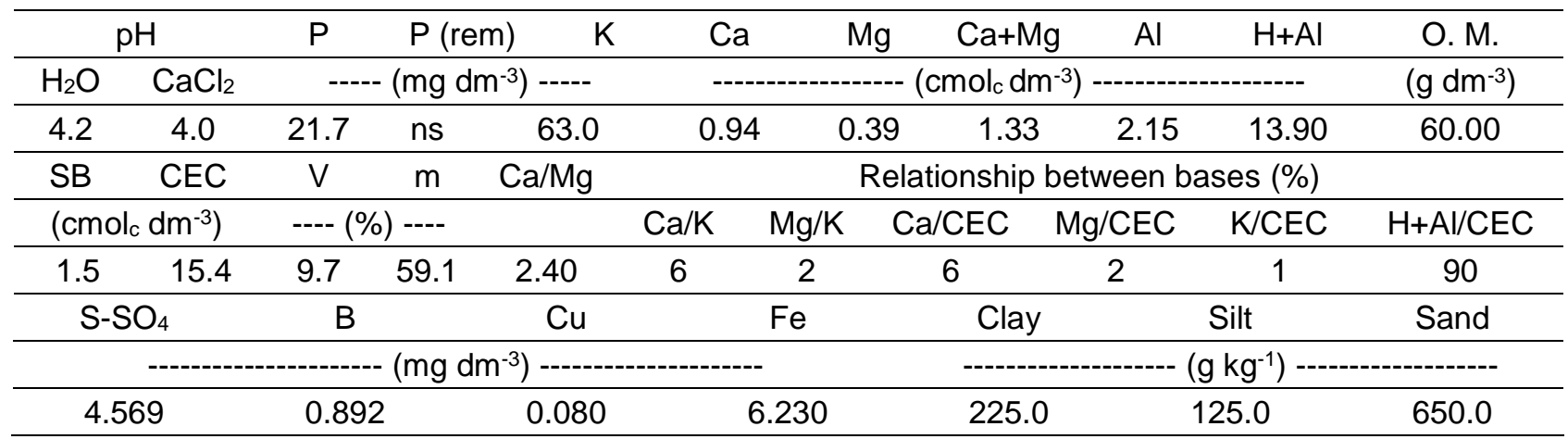

$\mathrm{K}$ and $\mathrm{P}$ - Mehlich-1; Ca, Mg and $\mathrm{Al}-\mathrm{KCl} 1 \mathrm{~mol} \mathrm{L-1} ; \mathrm{H}+\mathrm{Al}$ - Calcium acetate; SB - Sum of bases ; CEC (T) - Cation exchange capacity to $\mathrm{pH} 7,0 ; \mathrm{V}$ - Base saturation index; $\mathrm{m}$ - Aluminum saturation; O. M. = Organic matter - Oxidation with $\mathrm{Na}_{2} \mathrm{Cr}_{2} \mathrm{O}_{7} 4$ mol $\mathrm{L}^{-1}+\mathrm{H}_{2} \mathrm{SO}_{4} 10 \mathrm{~mol} \mathrm{~L}^{-1}$.

Table 2 - Chemical composition of the residues of soybean, sugarcane, cotton, chicken manure and bovine manure used as substrates in the production of papaya seedlings in the municipality of Nova Xavantina-MT.

\begin{tabular}{|c|c|c|c|c|c|c|}
\hline \multirow{2}{*}{ Residues } & $\mathrm{N}$ & $P$ & $\mathrm{~K}$ & $\mathrm{Ca}$ & $\mathrm{Mg}$ & $S$ \\
\hline & \multicolumn{6}{|c|}{$(\%)$} \\
\hline Soybean & 3.725 & 0.616 & 1.400 & 0.859 & 0.457 & 3.126 \\
\hline Sugarcane & 1.805 & 0.373 & 2.220 & 1.709 & 0.365 & 3.829 \\
\hline Cotton & 0.765 & 0.279 & 0.640 & 0.409 & 0.203 & 2.724 \\
\hline Chicken manure & 0.230 & 1.760 & 0.450 & 2.120 & 0.030 & 0.050 \\
\hline Cattle manure & 0.320 & 0.800 & 0.450 & 0.150 & 0.190 & 0.050 \\
\hline \multirow{2}{*}{ Residues } & $\mathrm{Na}$ & $\mathrm{Zn}$ & $\mathrm{Cu}$ & $\mathrm{Mn}$ & $\mathrm{Fe}$ & $\mathrm{B}$ \\
\hline & \multicolumn{6}{|c|}{$\begin{array}{l} \\
\end{array}$} \\
\hline Soybean & 0.002 & 0.005 & 0.001 & 0.010 & 1.178 & 0.002 \\
\hline Sugarcane & 0.005 & 0.003 & 0.001 & 0.006 & 1.542 & 0.006 \\
\hline Cotton & 0.066 & 0.004 & 0.002 & 0.014 & 0.625 & 0.001 \\
\hline Chicken manure & nd & 0.020 & 0.000 & 0.030 & 3.140 & 0.040 \\
\hline Cattle manure & nd & 0.010 & 0.000 & 0.040 & 0.300 & 0.040 \\
\hline
\end{tabular}

nd $=$ not determined

The cultural treatments were daily irrigation with the aid of irrigator, and manual control of weeds; no additional fertilization was performed.

Sixty-seven days after sowing, the following characteristics were evaluated: plant height, with the aid of a millimeter ruler, from the neck to the leaf blade of the highest leaf, and expressed in $\mathrm{cm}$; stem diameter, expressed in millimeters $(\mathrm{mm})$, to $2 \mathrm{~cm}$ above the plant lap, with the aid of a digital caliper; number of leaves per plant (fully expanded leaves); fresh (g) and dry (g) mass of shoots and roots.

The plants were removed from the plastic bags and the roots washed with running water to remove the substrate adhered thereto. Afterwards, they were sectioned in the plant lap region, separating the shoots from the roots. Subsequently, they were packed in paper bags and weighed in a precision balance (Brand: Shimadzu; Model: DL3200H; Country: Philippines $( \pm 0.01 \mathrm{~g})$ ), obtaining the fresh mass value (g). After this procedure, the bags were placed in an oven at $65 \stackrel{\circ}{\circ} \mathrm{C}$ until constant weight. The bags were removed and weighed again to obtain the dry mass of shoots and roots (Morais et al., 2017).

Analysis of variance was performed, and the means of the treatments containing residues were compared by Tukey test at $5 \%$ probability using the statistical software Sisvar (Ferreira, 2014). The comparison of means between the control and the other treatments was done by Dunnett test at $5 \%$ probability.

\section{Results and discussion}

It can be observed in Table 3 that there was a significant interaction between the factors (residues $x$ ratios) for all characteristics evaluated, and a significant difference for the contrast between the control (soil) and the factorial. The unfolding of interactions was carried out. 
Table 3 - Analysis of variance for the characteristics height (H), stem diameter (D) and leaf number (LN), shoot fresh mass (SFM) and shoot dry mass (SDM) and root fresh mass (RFM) and root dry mass (RDM) of papaya seedlings produced in substrates containing different proportions of residues.

\begin{tabular}{lcccccccc}
\hline \multirow{2}{*}{ Fonte de variação } & & \multicolumn{7}{c}{ Mean squares } \\
\cline { 2 - 8 } & FD & $\mathrm{H}$ & $\mathrm{D}$ & $\mathrm{LN}$ & $\mathrm{SFM}$ & $\mathrm{RFM}$ & $\mathrm{SDM}$ & $\mathrm{RDM}$ \\
\hline Blocks & 2 & $3.11^{\text {ns }}$ & $0.13^{\text {ns }}$ & $0.35^{\text {ns }}$ & $0.04^{\text {ns }}$ & $0.05^{\text {ns }}$ & $0.00^{\text {ns }}$ & $0.00^{\text {ns }}$ \\
Residue (R) & 4 & $185.99^{* *}$ & $10.77^{* *}$ & $22.40^{* *}$ & $21.04^{* *}$ & $6.85^{* *}$ & $0.49^{* *}$ & $0.02^{* *}$ \\
Proportion (P) & 1 & $17.04^{\text {ns }}$ & $1.55^{\star *}$ & $3.98^{* *}$ & $40.02^{* *}$ & $4.51^{* *}$ & $0.17^{* *}$ & $0.02^{* *}$ \\
R X P & 4 & $58.44^{* *}$ & $2.01^{* *}$ & $3.00^{* *}$ & $13.03^{* *}$ & $1.42^{* *}$ & $0.10^{* *}$ & $0.00^{* *}$ \\
Factorial x Control & 1 & $351.80^{* *}$ & $20.35^{* *}$ & $103.88^{* *}$ & $35.11^{* *}$ & $7.42^{* *}$ & $0.75^{* *}$ & $0.03^{* *}$ \\
Error & 20 & 5.90 & 0.13 & 0.86 & 0.29 & 0.07 & 0.006 & 0.001 \\
\hline CV (\%) & & 17.23 & 9.21 & 6.96 & 16.70 & 17.26 & 13.79 & 19.17 \\
\hline
\end{tabular}

$\mathrm{FD}=$ freedom degrees, $\mathrm{CV}=$ coeficient of variation, ${ }^{\mathrm{ns}}$ not significant, ${ }^{*}$ significant at $5 \%$ probability and ${ }^{* *}$ significant at $1 \%$ probability

Regarding the plant height of papaya seedlings, it was verified that in the ratio $1: 2$, the residues of sugarcane, cotton, and cattle manure promoted higher growth, leading to a higher plant height, that is, 22.32, 18.76, and $19.61 \mathrm{~cm}$, respectively (Table 4). However, in the ratio $1: 4$, cattle manure, chicken manure, and cotton residue allowed higher plant heights, of 21.61 , 17.86 , and $15.87 \mathrm{~cm}$, respectively, to the detriment of sugarcane and soybean residues (Table 4).

Table 4 - Height and stem diameter of papaya seedlings produced on substrates containing different proportions of residues.

\begin{tabular}{|c|c|c|c|c|}
\hline \multirow{2}{*}{ Residues } & \multicolumn{2}{|c|}{ Height $(\mathrm{cm})$} & \multicolumn{2}{|c|}{ Stem diameter (mm) } \\
\hline & Residue:Soil (1:2) & Residue:Soil (1:4) & Residue:Soil (1:2) & Residue:Soil (1:4) \\
\hline Soybean & 6.24 c A & $5.41 \mathrm{C} \mathrm{A}$ & $2.12 \mathrm{~d} \mathrm{~A}$ & 1.97 c A \\
\hline Sugarcane & 22.32 a $A$ & $11.13 \mathrm{bc} B$ & $5.32 \mathrm{ab} A$ & $3.55 \mathrm{~b} B$ \\
\hline Cotton & 18.76 a $A$ & $15.87 \mathrm{ab} A$ & $5.02 \mathrm{~b}$ A & 3.94 b B \\
\hline Cattle manure & 19.61 a $A$ & 21.61 a $A$ & 6.04 a $A$ & 5.46 a A \\
\hline Chicken manure & $12.48 \mathrm{~b} \mathrm{~B}$ & 17.86 a A & 3.53 c B & 4.84 a $A$ \\
\hline MSD1 & \multirow{2}{*}{\multicolumn{2}{|c|}{$\begin{array}{l}5.90 \\
4.13\end{array}$}} & \multicolumn{2}{|c|}{0.88} \\
\hline MSD2 & & & \multicolumn{2}{|c|}{0.61} \\
\hline
\end{tabular}

Means followed by the same lowercase letter in the column and upper case in the row do not differ statistically from each other by the Tukey test at 5\% probability. MSD - minimum significant difference; MSD1 - residue; MSD2 - proportions.

It can be inferred that the sugarcane residue provides higher plant height when used in a higher proportion in the mixture residue:soil $(1: 2)$. Cotton residue and cattle manure led to a higher height both in the ratio $1: 2$ (18.76 and $19.61 \mathrm{~cm}$, respectively) and $1: 4$ (15.87 and $21.61 \mathrm{~cm}$, respectively), with no difference among these ratios used.

According to Klein (2015), after analyzing the physical properties of the sugarcane residue, the substrate formulated with this plant material has characteristics that make it acceptable for the purpose of seedling production, such as total porosity considered good (above $0.50 \mathrm{~m}^{3} \mathrm{~m}^{-3}$ ) and particle stability. Trindade et al. (2000) reported that the addition of up to $30 \%$ cattle manure in the formulation of substrates for the production of papaya seedlings provided an increase in growth, height, and dry mass, similar to the results of this work. The use of cotton residues for agricultural purposes has shown beneficial results for plant growth and development, favored by improvements in the soil physical quality (Caldeira, 2008). Costa et al. (2007), evaluating the production of tomato seedlings in substrates composed of different ratios of coconut fiber and cotton residue from the textile industry, verified larger stem diameter, plant height, and fresh and dry mass of the roots and shoots in substrates containing $100 \%$ cotton residue.

The substrate composed of chicken manure provided higher height when used in the lowest ratio (1:4). Paixão et al. (2012), when evaluating the growth of papaya seedlings produced in substrates formulated with chicken manure and simple superphosphate doses, observed lower height, stem diameter, and dry mass of roots when using higher ratios $(40 \% \mathrm{v} / \mathrm{v})$.

The soybean residue was not efficient in the growth of the papaya seedlings, providing lower averages than the other substrates tested (Table 4). Similar results were obtained for stem diameter, with a positive effect of the use of plant and animal residues for this characteristic (Table 4). Treatments containing sugarcane and cotton residue produced seedlings with a larger diameter when used in the ratio 1:2 (5.32 and $5.02 \mathrm{~mm}$, respectively), while treatments containing cattle manure showed no difference in stem diameter 
when using the ratios $1: 2$ and 1:4 (6.04 and $5.46 \mathrm{~mm}$, respectively). Chicken manure provided a larger seedling stem diameter when used in the ratio 1:4 $(4.84 \mathrm{~mm})$, and the soybean residue provided smaller averages for the diameter when compared to the other residues used (Table 4).
For the parameter number of leaves, treatments containing sugarcane residue, cotton residue, cattle manure, and chicken manure provided a greater number of leaves, regardless of the ratio used (Table 5). The substrate containing soybean residue had a lower number of leaves in the two ratios tested.

Table 5 - Number of leaves of papaya seedlings produced on substrates containing different proportions of residues.

\begin{tabular}{lcc}
\hline \multirow{2}{*}{ Residues } & \multicolumn{2}{c}{ Number of leaves } \\
\cline { 2 - 3 } & Residue:soil (1:2) & Residue:soil (1:4) \\
\hline Soybean & $8.10 \mathrm{~b} \mathrm{~A}$ & $5.40 \mathrm{~b} \mathrm{~B}$ \\
Sugarcane & $11.85 \mathrm{a} \mathrm{A}$ & $10.40 \mathrm{a} \mathrm{A}$ \\
Cotton & $10.46 \mathrm{a} \mathrm{A}$ & $10.10 \mathrm{a} \mathrm{A}$ \\
Cattle manure & $11.71 \mathrm{a} \mathrm{A}$ & $11.55 \mathrm{a} \mathrm{A}$ \\
Chicken manure & $10.10 \mathrm{ab} \mathrm{A}$ & $11.14 \mathrm{a} \mathrm{A}$ \\
\hline
\end{tabular}

MSD1 $=2,26$ MSD2 $=1,57$

Means followed by the same lowercase letter in the column and upper case in the row do not differ statistically from each other by the Tukey test at 5\% probability. MSD - minimum significant difference; MSD1 - residue; MSD2 - proportions

Positive results were also found by other authors for the use of cattle manure in substrates for seedlings. Pontes et al. (1991) verified that in the production of papaya seedlings, the substrate composed of cattle manure + soil (1:3) presented positive results for height, diameter, number of leaves, and dry mass of roots.

Table 6 shows that in the ratio 1:2, treatments containing sugarcane residue $(7.16 \mathrm{~g})$, cotton residue $(6.09 \mathrm{~g})$, and cattle manure $(7.19 \mathrm{~g})$ promoted a higher fresh mass of shoots of the papaya seedlings in relation to the other residues tested. The treatment containing chicken manure provided a higher fresh mass of shoots when used in the ratio 1:4 (4.95 g). Substrates containing soybean residues in the ratios $1: 2$ $(0.72 \mathrm{~g})$ and $1: 4(0.39 \mathrm{~g})$ presented lower fresh mass of shoots. Regarding the dry mass of shoots, it was verified that the treatments composed of cattle manure $(0.96 \mathrm{~g})$ and sugarcane residue $(0.911 \mathrm{~g})$, in the ratio $1: 2$, provided a larger mass when compared to the other treatments tested, followed by the cotton residue $(0.70 \mathrm{~g})$. Lower masses were obtained in the treatments composed of soybean residue. Chicken manure promoted higher mass when used in lower ratios (1:4) (Table 6).

Table 6 - Shoot fresh mass (SFM) and shoot dry mass (SDM) of papaya seedlings produced on substrates containing different proportions of residues.

\begin{tabular}{|c|c|c|c|c|}
\hline \multirow{2}{*}{ Residue } & \multicolumn{2}{|c|}{ SFM (g plant ${ }^{-1}$ ) } & \multicolumn{2}{|c|}{ SDM (g plant $\left.{ }^{-1}\right)$} \\
\hline & Residue:Soil $(1: 2)$ & Residue:Soil $(1: 4)$ & Residue:Soil $(1: 2)$ & Residue:Soil (1:4) \\
\hline Soybean & 0.72 с A & $0.39 \mathrm{~d} \mathrm{~A}$ & $0.11 \mathrm{~d} \mathrm{~A}$ & $0.06 \mathrm{~d} \mathrm{~A}$ \\
\hline Sugarcane & 7.16 a $A$ & $2.27 \mathrm{c} \mathrm{B}$ & 0.91 a A & $0.37 \mathrm{c} \mathrm{B}$ \\
\hline Cotton & 6.09 a A & $1.46 \mathrm{~cd} \mathrm{~B}$ & $0.70 \mathrm{~b} \mathrm{~A}$ & $0.51 \mathrm{bc} \mathrm{B}$ \\
\hline Cattle manure & 7.19 a A & $3.63 \mathrm{~b} \mathrm{~B}$ & 0.96 a $\mathrm{A}$ & 0.77 a B \\
\hline Chicken manure & $3.12 \mathrm{~b} \mathrm{~B}$ & 4.95 a A & $0.41 \mathrm{c} \mathrm{B}$ & $0.61 \mathrm{ab} A$ \\
\hline MSD1 & \multirow{2}{*}{\multicolumn{2}{|c|}{$\begin{array}{l}1.31 \\
0.91\end{array}$}} & \multirow{2}{*}{\multicolumn{2}{|c|}{$\begin{array}{l}0.18 \\
0.13\end{array}$}} \\
\hline MSD2 & & & & \\
\hline
\end{tabular}

Means followed by the same lowercase letter in the column and upper case in the row do not differ statistically from each other by the Tukey test at $5 \%$ probability. MSD - minimum significant difference; MSD1 - residue; MSD2- proportions.

Regarding the fresh mass of roots, the treatments composed of cattle manure $(3.28 \mathrm{~g})$, chicken manure $(2.77 \mathrm{~g})$, and cotton residue $(2.73 \mathrm{~g})$ stood out in the ratio $1: 2$. In the ratio $1: 4$, chicken manure $(2.66 \mathrm{~g})$ and cattle manure $(2.18 \mathrm{~g})$ were highlighted (Table 7).

There was a higher dry mass of roots in the treatment composed of cattle manure (1:2) $(0.231 \mathrm{~g})$, followed by the treatments composed of sugarcane
$(0.182 \mathrm{~g})$ and cotton $(0.181 \mathrm{~g})$ residues, in the same ratio (Table 7). Lower values of dry mass of roots were obtained in the seedlings produced on substrates containing soybean residue in the two ratios used, possibly due to the imbalance caused by excess nitrogen in this substrate (Table 2). The sugarcane residue presents adequate chemical composition, capable of providing good development to the plants (Cunha et 
al., 2005); moreover, it improves the physical characteristics with the increase of macropores, and its use contributes to the decrease of its accumulation in the environment (Dutra et al., 2013). Serrano et al. (2006), evaluating the production of passion fruit seedlings on substrates formulated with residues from the sugarcane industry, verified a higher growth of seedlings in the substrates composed of the mixture sugarcane bagasse + filter cake (3:2; v:v), fertilized with $7.3 \mathrm{~kg} \mathrm{~m}^{-3}$ of Osmocoteß (14-14-14).

Table 7 - Root fresh mass (RFM) and root dry mass (RDM) of papaya seedlings produced on substrates containing different proportions of residues.

\begin{tabular}{lcccc}
\hline \multirow{2}{*}{ Residues } & \multicolumn{2}{c}{ RFM $\left(\mathrm{g} \mathrm{plant}^{-1}\right)$} & \multicolumn{2}{c}{ RDM (g plant $\left.{ }^{-1}\right)$} \\
\cline { 2 - 5 } Soybean & Residue:Soil $(1: 2)$ & Residue:Soil (1:4) & Residue:Soil (1:2) & Residue:Soil (1:4) \\
\cline { 2 - 6 } Sugarcane & $0.18 \mathrm{c} \mathrm{A}$ & $0.18 \mathrm{c} \mathrm{A}$ & $0.022 \mathrm{c} \mathrm{A}$ & $0.016 \mathrm{c} \mathrm{A}$ \\
Cotton & $1.48 \mathrm{~b} \mathrm{~A}$ & $1.58 \mathrm{~b} \mathrm{~A}$ & $0.182 \mathrm{ab} \mathrm{A}$ & $0.077 \mathrm{~b} \mathrm{~B}$ \\
Cattle manure & $2.73 \mathrm{a} \mathrm{A}$ & $0.39 \mathrm{c} \mathrm{B}$ & $0.181 \mathrm{ab} \mathrm{A}$ & $0.058 \mathrm{bc} \mathrm{B}$ \\
Chicken manure & $3.28 \mathrm{a} \mathrm{A}$ & $2.18 \mathrm{a} \mathrm{B}$ & $0.231 \mathrm{a} \mathrm{A}$ & $0.153 \mathrm{a} \mathrm{B}$ \\
\hline MSD1 & $2.77 \mathrm{a} \mathrm{A}$ & $2.66 \mathrm{a} \mathrm{A}$ & $0.115 \mathrm{~b} \mathrm{~A}$ & $0.148 \mathrm{a} \mathrm{A}$ \\
MSD2 & \multicolumn{3}{|c}{0.07} \\
\hline
\end{tabular}

Means followed by the same lowercase letter in the column and upper case in the row do not differ statistically from each other by the Tukey test at 5\% probability. MSD - minimum significant difference; MSD1 - residue; MSD2 - proportions.

Cattle manure improves the physical, chemical, and biological conditions of the substrate, providing nutrients to the plants and increasing the cation exchange capacity, water retention, soil porosity, and substrate aggregation (Schorn \& Formento, 2003).Hoffmann et al. (2001) observed positive results in the fresh and dry mass of papaya seedlings with the use of cattle manure in the formulation of substrates, possibly due to the greater availability of nutrients that the manure provides to the plant, influencing the emis- sion and size of leaves and the rate of photoassimilates.

It can be seen from Table 8 that the control (soil) differed statistically from the treatments in which organic residues were used, except for the soybean residue, which, for most of the evaluated characteristics, did not differ from the control. Thus, the use of organic vegetable or animal waste, with the exception of soybean residue, is recommended in the formulation of substrates.

Table 8 - Contrast of averages between the control (soil) and the substrates formulated with organic residues in different proportions for plant height $(H)$, Stem diameter (D), number of leaves (LN), fresh mass of shoot (SFM), fresh mass of root (RFM), dry mass of shoot (SDM), and dry mass of root (RDM).

\begin{tabular}{lccccccc}
\hline Treatments & $\begin{array}{c}\mathrm{H} \\
(\mathrm{cm})\end{array}$ & $\begin{array}{c}\mathrm{D} \\
(\mathrm{cm})\end{array}$ & LN & $\begin{array}{c}\text { SFM } \\
(\mathrm{g})\end{array}$ & $\begin{array}{c}\text { RFM } \\
(\mathrm{g})\end{array}$ & $\begin{array}{c}\text { SDM } \\
(\mathrm{g})\end{array}$ & $\begin{array}{c}\text { RDM } \\
(\mathrm{g})\end{array}$ \\
\hline Soybean (1:2) & 6.24 & 2.12 & $8.10^{*}$ & 0.72 & 0.18 & 0.11 & 0.022 \\
Soybean (1:4) & 5.41 & 1.97 & 5.40 & 0.39 & 0.18 & 0.06 & 0.016 \\
Sugarcane (1:2) & $22.32^{*}$ & $5.32^{*}$ & $11.85^{*}$ & $7.16^{*}$ & $1.48^{*}$ & $0.91^{*}$ & $0.182^{*}$ \\
Sugarcane (1:4) & $11.13^{*}$ & $3.55^{*}$ & $10.40^{*}$ & $2.27^{*}$ & $1.58^{*}$ & $0.37^{*}$ & $0.077^{*}$ \\
Cotton (1:2) & $18.76^{*}$ & $5.02^{*}$ & $10.46^{*}$ & $6.09^{*}$ & $2.73^{*}$ & $0.70^{*}$ & $0.181^{*}$ \\
Cotton (1:4) & $15.87^{*}$ & $3.94^{*}$ & $10.10^{*}$ & $1.46^{*}$ & 0.39 & $0.51^{*}$ & 0.058 \\
Cattle manure (1:2) & $19.61^{*}$ & $6.04^{*}$ & $11.71^{*}$ & $7.19^{*}$ & $3.28^{*}$ & $0.96^{*}$ & $0.231^{*}$ \\
Cattle manure (1:4) & $21.61^{*}$ & $5.46^{*}$ & $11.55^{*}$ & $3.63^{*}$ & $2.18^{*}$ & $0.77^{*}$ & $0.153^{*}$ \\
Chicken manure a (1:2) & $12.48^{*}$ & $3.53^{*}$ & $10.10^{*}$ & $3.12^{*}$ & $2.77^{*}$ & $0.41^{*}$ & $0.115^{*}$ \\
Chicken manure (1:4) & $17.86^{*}$ & $4.84^{*}$ & $11.14^{*}$ & $4.95^{*}$ & $2.66^{*}$ & $0.61^{*}$ & $0.148^{*}$ \\
Control (soil) & 3.77 & 1.45 & 3.91 & 0.11 & 0.05 & 0.01 & 0.005 \\
\hline MSD & 5.90 & 0.87 & 2.25 & 1.31 & 0.64 & 0.18 & 0.007 \\
\hline
\end{tabular}

$\mathrm{MSD}=$ minimum significant difference; *Significant by Dunnett test $(p<0.05)$

With these results, it can be inferred that the use of organic residues favored the growth of the papaya seedlings when compared to the control (soil). The main benefit of the use of organic residues from the agricultural point of view is the ability of these materials to provide nutrients, leading to the maintenance of or increasing the soil organic matter content (Pires \& Mattiazzo, 2008). 


\section{Conclusion}

The substrates containing cattle manure, sugarcane residue, and cotton residue in the ratio 1:2 (residue:soil) provided greater growth of the papaya seedlings. Alternatively, chicken manure may be employed provided it is used in the ratio 1:4.

\section{References}

Almeida LVB, Marinho CS, Muniz RA, Carvalho AJC (2012) Disponibilidade de nutrientes e crescimento de porta-enxertos de citros fertilizados com fertilizantes convencionais e de liberação lenta. Revista Brasileira de Fruticultura 34(1):289-296.

Anjos DC, Hernandez FFF, Costa JMC, Caballero SSU, Moreira VOG (2015) Fertilidade do solo, crescimento e qualidade de frutos do mamoeiro Tainung sob fertirrigação com potássio. Revista Ciência Agronômica 46 (4): 774-785.

Araújo AC, Araújo AC, Dantas MKL, Pereira WE, Aloufa MAI (2013) Utilização de substratos orgânicos na produção de mudas de mamoeiro Formosa. Revista Brasileira de Agroecologia 8(1): 210-216.

Araújo WBM, Alencar RD, Mendonça V, Medeiros E V, Andrade R C Rychardson Rocha de Araújo (2010) Esterco caprino na composição de substratos para formação de mudas de mamoeiro. Ciência e Agrotecnologia 34(1):68-73.

Bonatti V F B, Moreira E R, Souza P T (2017) Substratos orgânicos na produção de mudas de mamão 'Sunrise Solo'. Tecnologia \& Ciência Agropecuária 11 (3):31-35.

Caldeira MVW, Blum $\mathrm{H}$, Balbinot $\mathrm{R}$ Lombardi KC (2008) Uso do resíduo de algodão no substrato para produção de mudas florestais. Revista Acadêmica: Ciências Agrárias e Ambientais 6(2):191-202.

Costa CA, Ramos SJ, Sampaio RA, Guilherme DO, Fernandes LA (2007) Fibra de coco e resíduo de algodão para substrato de mudas de tomateiro. Horticultura Brasileira 25(3):387-391.

Cunha AO, Andrade LA, Bruno RLA, Silva JAL, Souza VC (2005) Efeitos de substratos e das dimensões dos recipientes na qualidade das mudas de Tabebuia impetiginosa (Mart. Ex D.C.) Standl. Revista Árvore 29(4): 507-516.

Dutra TR, Massad MD, Sarmento MFQ, Oliveira JC (2013) Substratos alternativos e métodos de quebra de dormência para produção de mudas de canafístula. Revista Ceres 60(1):72-78.

Ferreira, D F (2014) Sisvar: a guide for its bootstrap procedures in multiple comparisons. Ciência e Agrotecnologia 38(2), 109-112.
Finatto J, Altamayer T, Martini MC, Rodrigues M, Basso V, Hoehne L (2013) A importância da utilização da adubação orgânica na agricultura. Revista Destaques Acadêmicos 5(4):85-93.

Hoffmann I, Gerling D, kyogwom UB, Manebielfeldt A (2001) Farmers management strategies to maintain soil fertility in a remote area in northwest Nigeria. Agriculture, Ecosystems \& Environment 86(3):263-275.

Klein C (2015) Utilização de substratos alternativos para produção de mudas. Revista Brasileira de Energias Renováveis 4(3):43-63.

Köppen W, Geiger R (1928) Klimate der Erde. Gotha: Verlag Justus Perthes. Wall-map $150 \mathrm{~cm} \times 200 \mathrm{~cm}$.

Korndörfer GH (2015) Adubação Orgânica. 17p. Apostila Adubos Orgânico. Disponível em $<$ http://www.dpv24.iciag.ufu.br/new/dpv24/Apostilas/Ap ostila\%20Ad.\%20Organicos\%2003.pdf > (Acesso em 09 dez 2016).

Krause MR, Monaco PAVL, Haddade IR, Meneghelli LAM, Souza TD (2017) Aproveitamento de resíduos agrícolas na composição de substratos para produção de mudas de tomateiro. Horticultura Brasileira 35 (2):305-310.

Kusdra, JF, Moreira DF, Silva SS, Araújo-Neto SE, Silva RG (2008) Uso de coprólitos de minhoca na produção de mudas de mamoeiro. Revista Brasileira de Fruticultura 30(2):492-497.

Lima LKS, Santos JPS, Silva, MJR, Gomes RN, Santos WB, Araújo AE (2011) Produção de mudas de mamoeiro com substrato orgânico e sementes de duas origens. Revista Brasileira de Agroecologia 6 (1): 1-6.

Malavolta E, Pimentel-Gomes F, Alcarde JC (2002) Adubos e adubações. Nobel. 29p.

Melo APC, Seleguini A, Pereira JM, Neto AR, Wisintainer C, Neves RG, Camilo YMV (2015) Maturação de frutos e tratamento pré-germinativo na produção de mudas de mamão. Revista de Ciências Agrárias 38 (3):330-337.

Morais TL, Costa AC, Menezes M, Souza ME (2017) Produção de mudas de mamoeiro em função de diferentes substratos. Cultivando o Saber 10 (4): 408- 420.

Oliveira AMG, Farias ARN, Filho HPS, Oliveira JRP, Dantas JLL, Santos LB, Oliveira MA, Junior MTS, Silva MJ, Almeida OA., Nickel O, Medina VM, Cordeiro ZJM (1994) Propagação e plantio: mamão para exportação, aspectos técnicos da produção. EMBRAPA/SPI. 22p. 
Paixão MVS, Schmildt ERS, Mattiello HN, Ferreguetti GA, Alexandre RS (2012) Frações orgânicas e mineral na produção de mudas de mamoeiro. Revista Brasileira de Fruticultura 34(4):1105-1112.

Penteado SR (2003) Introdução à agricultura orgânica. Viçosa. 130p.

Pires AMM, Mattiazzo MA (2008) Avaliação de Viabilidade do Uso de Resíduos na Agricultura. Circular Técnica-EMBRAPA. 9p.

Pontes HM, Figueiredo AF, Melo B, Tucci CAF (1991) Substratos para a produção de mudas de mamoeiro (Carica papaya L.) na Amazônia Ocidental. Revista da Universidade do Amazonas. Série Ciências Agrárias 1(1):57-64.

Schorn LA, Formento S (2003) Silvicultura I: Produção de mudas florestas. Universidade Regional de Blumenau, Centro de Ciências Tecnológicas, Departamento de Engenharia Florestal. 55p.

Serrano LAL, Silva CMM, Ogliari J, Carvalho AJC, Marinho CS, Detmann E (2006) Utilização de substrato composto por resíduos da agroindústria canavieira para produção de mudas de maracujazeiro-amarelo. Revista Brasileira de Fruticultura 28 (3): 487-491.
Silva RBG, Simões D, Silva MR (2012) Qualidade de mudas clonais de Eucalyptus urophylla x E. grandis em função do substrato. Revista Brasileira de Engenharia Agrícola e Ambiental 16(3):297-302.

Silva RF, Eitelwein MT, Cherubin MR, Fabbris C, Weirich S, Pinheiro RR (2014) Produção de mudas de eucalyptus grandis em substratos orgânicos alternativos. Ciência Florestal 24(3):609-619.

Silva RF, Marco R, Ros CR, Almeida HS, Antoniolli ZI (2017) Influência de Diferentes Concentrações de Vermicomposto no Desenvolvimento de Mudas de Eucalipto e Pinus. Floresta e Ambiente 24(e): 1-10.

Torres GA, Tarifa LRM (2012) Aproveitamento de Resíduos Agrícolas. Dossiê técnico. 2012 Serviço Brasileiro de Respostas Técnicas - SBRT. Universidade de São Paulo - USP.

Trindade AV, Faria NG, Almeida FP (2000) Uso de esterco no desenvolvimento de mudas de mamoeiro colonizadas com fungos micorrízicos. Pesquisa Agropecuária Brasileira 35(7):1389-1394. 